\title{
A socioecological framework for research on work and obesity in diverse urban transit operators based on gender, race, and ethnicity
}

\author{
BongKyoo Choi ${ }^{1 *}$, Peter Schnall', Marnie Dobson ${ }^{1}$, Haiou Yang ${ }^{1}$, Dean Baker ${ }^{1}$ and YoungJu Seo ${ }^{2}$
}

\begin{abstract}
Urban transit (bus and rail) operators, totaling nearly 700,000 persons, are one of the heaviest occupational groups in the United States (US). Little is known about occupational risk factors for weight gain and obesity and their interrelationship with health-related behaviors, particularly among female minority (African Americans and Hispanics) transit operators who are at greater risk for obesity. As a step towards developing successful obesity interventions among urban transit operators, this paper aims to present a new socioecological framework for studying working conditions, chronic strain, health-related behaviors, weight gain/obesity, and obesity disparity in diverse urban transit operators based on gender, race, and ethnicity. Our framework is a synthesis of several different theories and disciplines: the resource-work load model (work stress), occupational ergonomics, the theory of intersectionality, and worksite health promotion. The framework was developed utilizing an extensive literature review, results from our on-going research on obesity, input from focus groups conducted with Los Angeles transit operators as well as interviews and meetings with transit operator stakeholders (management, unions, and worksite transit wellness program), and ride-along observations. Our hypotheses highlighted in the framework (see Fig. 1) are that adverse working conditions, largely characterized as a combination of high demands and low resources, will increase the risk for weight gain/obesity among transit operators directly through chronic strain and hypothalamic dysfunction (hyper-and hypo-activations), and indirectly through health-related behaviors and injuries/chronic severe pain. We also hypothesize that the observed increase in adiposity among female minority operators is due to their greater exposure to adverse occupational and non-occupational conditions that reflect their intersecting social identities of lower social class and being a minority woman in the US. Our proposed framework could greatly facilitate future transit worksite obesity studies by clarifying the complex and important roles of adverse working conditions in the etiology of weight gain/obesity and obesity disparity among transit operators and other working populations.
\end{abstract}

Keywords: Los Angeles, Minority, Work stress, Health behaviors, Weight gain, Injuries, Disparities

\section{Background}

There are about 5.7 million commercial motor vehicle operators, including 0.7 million bus and urban transit operators in the United States (US) [1-3]. Obesity $\left(>30 \mathrm{~kg} / \mathrm{m}^{2}\right.$ of body mass index (BMI)), an excessive accumulation of body fat, is a key health issue among US urban transit operators (bus and rail operators) [4-9].

\footnotetext{
* Correspondence: b.choi@uci.edu

${ }^{1}$ Center for Occupational and Environmental Health, University of California

Irvine, 100 Theory, Suite 100, Irvine, CA 92617, USA

Full list of author information is available at the end of the article
}

Urban transit operators (of whom $50 \%$ are minorities) [1] were ranked first and second in obesity prevalence among 41 US male and female occupational groups, respectively [4]. In addition, about $20-33 \%$ of transit operators are minority women $[1,5]$ who have a much higher prevalence of obesity compared to male and other female operators $(52-65 \%$ vs. $37-41 \%)$ [9]. Urban transit operators also have a high risk of hypertension, metabolic syndrome, cardiovascular disease (CVD), Type II diabetes mellitus, depression, 
non-fatal occupational injuries, chronic back and neck pain, and sickness absence $[3,7,8,10-21]$.

Despite wide-spread recognition that obesity is a problem among transit operators, little is known about the occupational risk factors for weight gain and obesity in urban transit operators or the reasons for the much greater obesity risk in minority women (African Americans and Hispanics) transit operators [9, 22]. In addition, to the best of our knowledge, no successful transit worksite obesity intervention studies exist $[1,5]$. A search of the literature reveals two efforts: French et al. [5] conducted an 18-month worksite obesity intervention study mainly targeting increased availability of healthy vending machine choices at division buildings in transit operators in Minneapolis, USA. However, the intervention study did not successfully prevent or reduce obesity among transit operators. Another 18-month intervention study was carried out by Hedberg et al [23] for improving CVD risk factors among a group of German workers, including bus drivers. The contents of the interventions were health education and group or individual activities on exercise, diet, and stress coping. However, the level of BMI increased over the intervention period in both the intervention and control groups and no intervention effect on BMI was observed in the German study. Neither study addressed structural aspects of driving among transit operators.

One critical barrier to progress in worksite obesity studies among US transit operators is the lack of a good theoretical framework to guide research on work and weight gain/obesity. For example, the theoretical framework on work and health in transit operators by Ragland et al. [24] is too general to be used for research on work and obesity, although it suggests that high job demands and low job resources can increase the risk for disease and injury among transit operators through healthrelated behaviors or stress. No specific information about job demands or resources of transit operators as risk factors for obesity is available in their framework. Also, like most contemporary etiological frameworks on work and obesity in working populations [25] or of single occupational groups (e.g., professional firefighters) [26], their framework cannot explain appropriately the disparities in obesity by gender and race/ethnicity among US transit operators. Moreover, mechanistically, there is also no consideration in available frameworks [24-26] of the role of injuries/chronic severe pain that are prevalent among transit operators $[16,17,19,27]$ and which may function as a possible pathway from adverse working condition to weight gain/obesity.

The objective of this paper is to describe our newly developed socioecological framework for studying working conditions, chronic strain, health-related behaviors, weight gain/obesity, and obesity disparity among US transit operators (see Fig. 1). Compared to individualbased health behavior frameworks [28], socioecological frameworks on health and health behaviors [29-31] emphasize the influence of multi-level (e.g., micro-level, worksite; macro-level, community and society) environmental factors on individual's and group's health and health behaviors. Our framework is a synthesis of several different theories and disciplines: the theory of intersectionality (gender, and race/ethnicity), the resource-work load model (work stress), occupational ergonomics (work-related injuries and chronic musculoskeletal disorders), and worksite health promotion (for details, see below). This framework also incorporates results of our recently completed qualitative study that included five focus groups with 65 Los Angeles County Metropolitan Transit Authority (LACMTA) transit operators on work, health-related behaviors, and health (obesity) [32], as well as interviews and meetings with the representatives of the LACMTA management, the Sheet Metal Air Rail Transportation (SMART) local unions, and the SMARTMTA Trust Fund (a joint labor-management wellness program), and ride-along observations.

LACMTA employs over 4500 bus and 500 rail operators and provides bus and rail services to over 9 million Los Angeles county residents, who service over 500,000 riders per day. There are 18,500 stops on 189 lines in Metro Local and 22 Divisions spread throughout greater Los Angeles County. In 2006, the LACMTA began a wellness program as a joint labor-management program. The program includes a full-time wellness program coordinator and 1-2 bus or rail operators who work also as wellness ambassadors at each division. The ambassadors assist wellness activities at each division on "Wellness Wednesdays" and are paid from 9 am to $4 \mathrm{pm}$. They also participate in regular 1 -h wellness meetings with the program coordinator every other Thursday.

\section{Development of a new socioecological framework for studying working conditions, chronic strain, health-related behaviors, weight gain/obesity, and obesity disparity in urban transit operators}

Additional information on the role of occupational risk factors for obesity among transit operators is critical for designing more effective and sustainable obesity intervention programs for transit operators [33-37]. However, there has only been one cross-sectional epidemiological study [22] of occupational risk factors conducted in transit drivers and it examined only one occupational obesity risk factor: working more than $50 \mathrm{~h} /$ week was associated with higher BMI only in male transit operators. The study also found that long work hours were not associated with leisure-time exercise and consumption of fruits/vegetables in both male and female operators. But, in a small scale qualitative study 


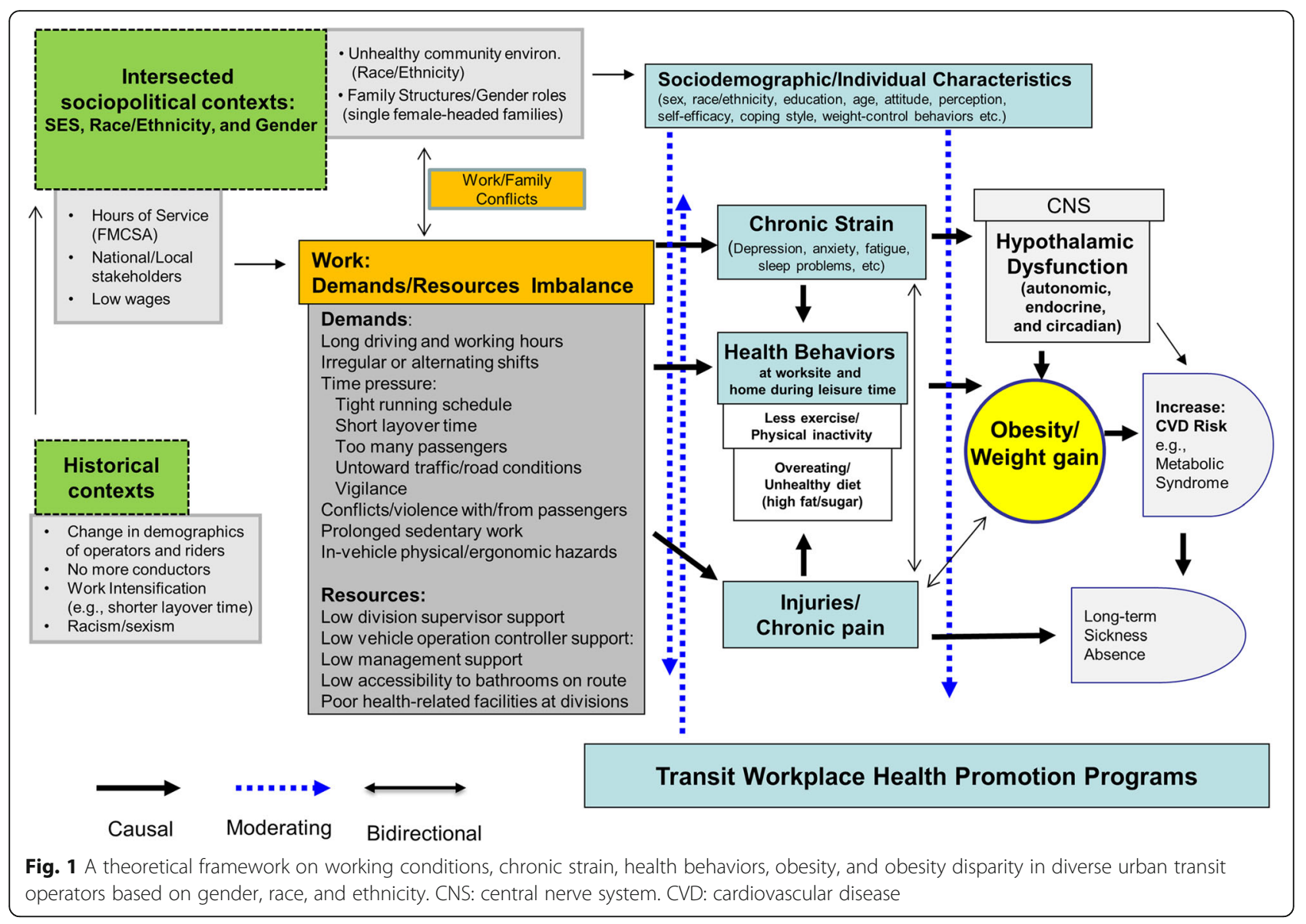

[38], some Australian urban transit operators reported shift work and irregular driving times as barriers to their physical activity at work and during leisure time.

On the other hand, there is emerging evidence for the longitudinal associations between adverse working conditions and weight gain/obesity in non-transit working populations $[39,40]$. The evidence is relatively strong for shift work [41-43] and long work hours [44-47] but as yet relatively weak for prolonged sedentary work [48-52], psychological job demands (time pressure and conflict demands) [53-56], job strain (a combination of low control and high psychological demands) [55, 57-59], and social support at work $[55,60]$. No studies have examined the unique work schedule system of urban transit operators, nor the multiple psychosocial stressors leading to chronic strain in relation to adiposity [39]. Also, as noted above, the evidence for the association between long work hours and obesity in transit operators is still limited.

\section{Work schedule system of urban transit operators}

Urban transit operators are among the few occupational groups in the US whose work hours are regulated by a nation-wide (federal) law. There is no nation-wide regulation limiting the maximum weekly work hours of the general working populations in the US. The mission of the US Federal Motor Carrier Safety Administration (FMCSA) within the Department of Transportation is to prevent commercial motor vehicle-related fatalities and injuries. According to the regulations on hours of service by the FMCSA, operators can drive up to $10 \mathrm{~h}$ /day and work up to $15 \mathrm{~h} /$ day. But they should have eight consecutive off-duty hours before driving again (https:// www.fmcsa.dot.gov/regulations/hours-service/summaryhours-service-regulations). Operator work schedules vary by whether they are extra-board members (who are low-seniority full-time operators on weekly or daily changing work schedules and frequently covering absent operators) and on a "straight" (not unusually starting very early or late, sometimes alternating), split shift (divided into two work periods with a $2-3 \mathrm{~h}$ non-work period), or mixed shift $[19,61]$. Urban transit agencies rely on overtime work of transit operators (particularly, extra-board operators) to deal with varying demands for bus and rail services by the time of day, the day of the week, and time of year [62]. Transit operators also have a strong incentive for overtime work because their 
hourly wage is low: as of 2015, the median hourly wage for US bus drivers was $\$ 14.88 / \mathrm{h}$ [10] and the top hourly wage for a "Tier 2" (hire after 1997) bus driver in the LACMTA was $\$ 23.94 / \mathrm{h}$ [32].

\section{Some adverse working conditions of transit operators may increase the risk for weight gain and obesity}

Typical working conditions of transit operators are relevant to studies of obesity. The earlier two-person crew system (one driver and one conductor) for operating the bus has been largely replaced with a singleperson (only one driver) system in major Western cities [12, 63]. Ethnic minority groups, particularly African Americans and Hispanic Americans, entered transit occupations in greater numbers after the 1970s with the closing of industrial manufacturing plants in Los Angeles urban areas [64]. Driving conditions have changed a great deal; for example, rest/recovery time of LACMTA transit operators at the end of each route has significantly decreased (e.g., $15-20 \mathrm{~min}$ in 1980 s to 6-10 $\mathrm{min}$ in 2006) [64] and traffic conditions have worsened in many areas due to increased vehicles utilizing the streets. Worsening traffic conditions increase the risk of accidents and injuries to passengers and drivers. Driving requires heightened vigilance by drivers, leading to chronic physiological arousal (as manifested by higher blood pressures while driving) [65] in drivers compared to other occupations.

Gardell and his colleagues [57] proposed a work stress model (the resource-work load model) for predicting health risks among Swedish transit operators. The model is similar to the Karasek's Demand-Control model [66]. However, the concept of work load in the resource-work load model is more specific for transit operators (e.g., lags behind the timetable, conflicts between timetable and safety, and conflicts between timetable and service) and the concept of resources is broader than the concept of control in the Karasek's Demand-Control model as it includes several multi-level, different aspects of resources: authority on the job (how to handle problematic passenger contacts), technical (radio and alarms systems for information and security), social (coworker and supervisor support), and organizational resources (resources available through trade unions). According to their model, the greatest health risk among transit operators is expected in those who are exposed to the combined working conditions of low resources and high work load. For our theoretical framework (Fig. 1), as compared to the resource-work load model, we adopt broader concepts of job demands and job resources as risk factors for obesity in transit operators.

We hypothesize that high job demands and low job resources are the most important occupational adiposity risk factors independently and in combination with each other (e.g., the resource-work load model) [61] among transit operators (Fig. 1). High job demands include long driving and work hours (e.g., $>70 \mathrm{~h} /$ week and $>12 \mathrm{~h} /$ day), irregular shifts (e.g., extra-board operators and alternating between very early and late shifts), conflicts with passengers and verbal and physical violence from passengers, prolonged sedentary work (e.g., $>85 \%$ of their work hours), time pressure, in-vehicle ergonomic hazards, and work and family conflict. Time pressure is defined here as efforts to maintain the running schedules while meeting possible competing demands of driving safely and serving the public [61, 67], including short layover time (a break time for operators' rest, eating, and access to the restroom at the end of each route). It could be operationalized as a multidimensional measure of short intervals between stops, high passenger load, high traffic load, constant threat avoidance vigilance (TAV), and short layover time. TAV is a concept advanced by Dr. Karen Belkic and her colleagues to describe work settings in which workers must maintain constant vigilance to avoid catastrophe exactly the situation faced by bus operators in urban areas [65]. Low job resources include low division supervisor/vehicle operation controller/management support, low accessibility to bathrooms (toilets) on route, and poor health-related facilities at divisions. All of these adverse working conditions were identified as stressful occupational factors or barriers to healthrelated behaviors in our pilot project with 65 operators [32], which is similar to qualitative work stress studies in British and Australian transit operators $[63,68]$.

We identified a substantial variation in each of the aforementioned occupational risk factors for obesity among LACMTA transit operators in our recent pilot study. For example, about $20 \%$ of LACMTA operators in our pilot project worked $>12 \mathrm{~h} /$ day and $14 \%$ worked $>70 \mathrm{~h} /$ week. We hypothesize that adiposity risk will be the highest in the long driving and working hour operators, particular in dense traffic areas imposing high time pressure and requiring greater TAV. Long driving and working hours were associated with obesity in recent truck driver studies [69, 70]. The Framingham 10 -year coronary heart disease risk scores were significantly greater in the bus drivers who worked long hours $(>12 \mathrm{~h} /$ day) than in those who worked regular work hours $(8 \mathrm{~h} /$ day $)$ in a Korean bus driver study [21]. We also hypothesize that adiposity risk will be higher in the operators doing irregular work shifts (vs. fixed shifts) and who are exposed to high time pressure (vs. low time pressure). While there has been an overall decrease in the layover time of transit operators since the 1980s [64], layover time varies significantly among individual operators $[71,72]$.

There is also a non-trivial variation in sedentary work time among transit operators: > 96 min during an 8-h 
work [73]. Sedentary work time of transit operators can accumulate during driving (driving time plus sitting time during layover time) and non-driving work hours [72] including waiting time for assignment at divisions [74]. We hypothesize that adiposity risk will be greater in the operators doing longer sedentary work ( $>85 \%$ of their work hours vs. $\leq 85 \%$ ) [73]. In addition, conflicts with passengers on the bus particular fare and verbal abuse and physical assaults are not rare, particularly in the routes that go through low-income communities. Poor in-vehicle ergonomic hazards (e.g., vibration and seat) [17] may increase adiposity risk among operators through work-related injuries/chronic pain (for details, see below). Also, emotional and information support from division supervisors and vehicle operation controllers are very important for operators' work performance and mental health [32]. Several LACMTA female operators in our pilot project reported more work and family conflict (child care and contact with children) when they worked longer particularly on irregular shifts.

\section{Etiological mechanisms for research on adverse working conditions and adiposity risk in diverse urban transit operators based on gender, race, and ethnicity}

We propose five important etiological mechanisms (Fig. 1) by which the aforementioned adverse working conditions can increase adiposity risk in operators. These five mechanisms are not mutually exclusive and multiple factors are likely to be active at the same time. The first three mechanisms are consistent with contemporary theoretical frameworks on work and obesity suggested previously by our group [26] and Pandalai et al [25]. But we further explicate the first mechanism (see below) and the last two mechanisms are newly presented here.

First, the aforementioned adverse working conditions of high job demands (except for prolonged sedentary work), low resources, or their combination may function as stressors to induce chronic strain (e.g., depression, anxiety, fatigue, and sleep problems) resulting in dysfunction of the hypothalamus [75-78] that could shift energy balance towards the positive via alterations of the autonomic nervous system, endocrine systems, and circadian rhythms in relation to lipid metabolism [75, 79-87]. For example, long and irregular work hours can result in short or poor sleep hours that are associated with BMI among drivers $[7,69]$.

Here we describe the first mechanism with a focus on lipid metabolism in detail from the neuropsychological, endrocrinological, and chronobiogical perspectives. The dysfunction of the hypothalamus includes both hyper- or hypo-activations of the hypothalamus. Cortisol is secreted by the activation of the hypothalamus-pituitaryadrenal cortex axis. The level of blood cortisol has a unique diurnal pattern in humans: a rapid increase just after wakening, the peak (acrophase) about $30 \mathrm{~min}$ after awaking, and the bottom (nadir) before bedtime. Depressed individuals had lower levels of cortisol than non-depressed individuals in the morning. However, in the afternoon, depressed individuals had higher levels of cortisol, but lower reactivity to a stressor, compared to non-depressed individuals [78]. It is also wellknown that patients with chronic use of corticosteroids become centrally obese and have an increased appetite [77]. High levels of cortisol may induce a resistance to leptin that is produced by adipocytes and increases satiety in the hypothalamus [77]. In rats, chronic exposure to high levels of corticosterone increased visceral adiposity, inhibited the lipolysis of triglycerides (stored fat) into fatty acids in mature adipocytes, and increased the differentiation of premature adipocytes into mature adipocytes (adipogenesis) [88].

Norepinephrine and epinephrine are released by the activation of the sympathetic nerve system that is under the control and coordination of the hypothalamus [87, 89]. The hormones increase lipolysis through $\beta$-(particularly its subtype, $\beta_{3}$ ) adrenergic receptors in adipocytes [79, 90-95]. It is known that chronic use of $\beta$-adrenergic receptor blockers as antihypertensive medications increase the risk for weight gain [96]. Under chronic stress, the adrenergically mediated lipolysis in adipocytes may be inhibited or impaired by high levels of cortisol. Cortisol represses $\beta_{3}$ - adrenergic receptor gene expression (transcription) in white and brown adipocytes in mice [90]. Interestingly, the adrenergically stimulated lipolysis in white adipocytes was blunted (reduced) in obese humans [79]. High cortisol levels may also decrease the thermogenesis of brown adipocytes $[92,93,97]$ by repressing the $\beta_{3}$ adrenergic receptor gene transcription in brown adipocytes, which remains to be tested in the future.

Disturbance of biological circadian rhythmicity can increase the risk for obesity given the reciprocal interrelationship between metabolism and circadian clocks $[87,98]$. The central master circadian clock is located at the suprachiasmatic nucleus of the hypothalamus, while the peripheral clocks are found in liver, pancreas, muscle, and adipose tissue. Several hormones and enzymes that are involved in lipid metabolism are under the control of the biological clocks and have their own circadian rhythms. For example, leptin has its peak level just after midnight in humans [99]. Sleep restriction in healthy men changed the leptin circadian rhythmicity (earlier peak time and dampened rhythmicity) and reduced the 24-h mean level of blood leptin [100]. In nocturnal mice, mice fed a high-fat diet during the day phase were significantly heavier than mice fed the isocaloric high-fat diet during the night phase [101]. 
Lipoprotein lipase in adipose tissue takes up fatty acids in blood for use and storage in adipose tissue. The gene expression for the lipase in adipose tissue after a normal or high-fat diet significantly increased in mice without a biological clock-related nuclear receptor (REV-ERB $\alpha$ ), while it did not change in mice with the receptor [102].

On the other hand, the aforementioned stressors may also increase the risk for elevated heart rate, hypertension, hyperlipidemia, hyperglycemia, arterial inflammation, and arrhythmia among transit operators through chronic psychological and physiological arousal, including activation of the hypothalamus and amygdala [65, 103-106] contributing to the development of the metabolic syndrome, atherosclerosis, and CVD. The increased CVD risk by the stressors may be a major contributor to high long-term sickness absence and workers' compensation claims in transit operators [10,18].

Second, the aforementioned adverse working conditions of high job demands (except for prolonged sedentary work), low resources, or their combination may cause obesity via changes in health behaviors (exercise and eating behaviors at worksite and home during leisure-time) [39, 107-115]. Some LACMTA operators in our pilot project reported that their work schedule (e.g., long work hours/overtime, irregular shift, and time pressure) forces them to eat fast and also they tend to eat a lot of "comfort foods" when stressed at work.

Third, low work-related physical activity (e.g., prolonged sedentary work), given a constant level of energy consumption, could lead to a positive energy imbalance state [116-118] contributing to weight gain.

Fourth, adverse working conditions of high job demands, low resources, or their combination may increase the risk for weight gain/obesity via work-related injuries $[16,17]$ or chronic severe pain on muscle/joints [27] that in turn affect health behaviors (e.g., exercise). In-vehicle ergonomic hazards, driving hours, and low supervisor support were associated with low back injury in transit operators $[16,17,119]$. Injury is one of the main obstacles to maintaining or adopting exercise in blue-collar workers $[23,120]$. Also, there may be a bidirectional relationship between severe chronic pain and sleep disturbance [121-123]: severe chronic pain may negatively affect sleep quality and mental health, which in turn reduces pain tolerance, and vice versa. On the other hand, adiposity can also increase the risk for injuries/chronic pain [124, 125].

Fifth, minority women operators may be exposed to more adverse occupational and non-occupational (community and family) conditions than male and other female operators. The theory of intersectionality [126-128] highlights the possible synergistic detrimental health effects of the combination of socioeconomic status, gender, and race/ethnicity. Crenshaw [126] developed the theory of intersectionality as a critique of a single-axis framework in antidiscrimination law, feminist theory, and antiracist politics in the 1980s: for example, in race discrimination discourses, a single axis (sex-based or class-based) approach is not appropriate for addressing the experiences of Black women who were multiply-burdened (i.e., low social class, women, and Black). Recently, several public health researchers have started to pay attention to the theory of intersectionality for research in multiple historically oppressed populations [127, 128]. We think that the theory of intersectionality serves as a theoretical basis for examining the intersected relationships of low social class, being a woman, and a member of a racial/ ethnic minority in understanding obesity disparities between minority women operators, and male and other female operators.

Female operators were more stressed from irritated and aggressive passengers and congested traffic conditions than male operators [129]. Also, several LACMTA female operators in our pilot project reported more work and family conflict (child care and contact with children) when they worked longer particularly on irregular shifts. Furthermore, long work hours, when combined with long domestic familial duties, may reduce leisure-time exercise of female operators [130]. All these factors are more likely to be experienced by minority women operators given the more common single female-headed families among African Americans (43\% vs. $13 \%$ among whites) [131], less accessible residential health promoting environments (e.g., parks and supermarkets providing healthy foods) in minority communities [132,133], and also racism and sexism in our society [134, 135]. Additionally, work stress coping behaviors and tolerance of heavier body weight may differ by gender and race/ethnicity [136-141], which further supports the possible differential relationships between working conditions, health behaviors, and adiposity among transit operators.

\section{Main study domains to be measured for empirically testing our theoretical framework}

In order to facilitate future worksite obesity studies among transit operators based on our new theoretical framework, we present a list of key domains that should be assessed with available instruments in the literature in the future studies.

- Working conditions: detailed work schedules, sedentary work time, time pressure (short intervals between stops, high passenger load, high traffic load, constant threat avoidance vigilance, and short layover time) $[61,66]$, coworker and supervisor support $[14,116,142]$, conflicts with passengers $[64,143]$, 
physical demands [142, 144], worksite food/ physical activity environment [145], worksite discrimination [146-148], and in-vehicle ergonomic hazards (eight-item scale about the seat, vibration, and heat/cold/draft) [17]

- Health behaviors at work and during leisure time: eating behaviors and exercise at worksite and at home [92, 108, 149, 150], including stress-induced overeating, weight control behaviors [151], and impaired exercise/physical activity due to work-related injuries/chronic severe pain in the past year [152]

- Health conditions: weight perception (body image), work-related injuries (resulting in $>2$ weeks of sickness absence in the past year) [153, 154], chronic severe pain on muscle/joints in the past year (lasting $>30$ days) [27, 119, 152], mental health (depression, exhaustion, sleep quality and hours. etc.), and chronic diseases (hypertension, hyperlipidemia, and diabetes)

- Community and family variables: neighborhood and community health promotion facilities [155], workfamily conflicts [156], and family structure variables including household head, number of young children, and household work hours [129]

- Sociodemographic variables: age, gender, race/ ethnicity, and individual and household income.

- Adiposity (weight, height, and waist circumference). For the calculation of BMI, measured weight and height. Also, waist circumference needs to be measured considering its stronger CVD prediction than BMI [157-159] and a possible overestimation of adiposity by BMI [160-162] in African

Americans. Obesity will be defined with the current standard cut-points for BMI $\left(>30 \mathrm{~kg} / \mathrm{m}^{2}\right)$ and WC ( $>40$ in. for men and $>35$ in. for women) [163]

\section{Conclusions}

In this paper, we proposed a socioecological framework for research on working conditions, chronic strain, health-related behaviors, weight gain/obesity, and obesity disparity in urban transit operators with diverse gender and race/ethnicity backgrounds (Fig. 1). Compared to our previous framework [26], we have further explicated some physiological mechanisms (e.g., dysfunction of hypothalamus) by which adverse working conditions increase the risk for obesity from the neuropsychological, endrocrinological, and chronobiogical perspectives. This new framework also provides further insight, when compared to our previous and other contemporary theoretical frameworks on work and obesity/health [24-26], in explaining the intersected obesity disparity between minority women transit operators and male and other female transit operators in the US. Our new framework, albeit exploratory, is unique in that it embraces and highlights injuries/chronic severe pain as a possible pathway from adverse working condition to weight gain/ obesity among transit operators who are at high risk for non-fatal occupational injuries and chronic back and neck pain.

\section{Comparisons with our previous framework for research on work and obesity in professional firefighters}

Our new framework for research on work and obesity in transit operators described in this paper is a self-critical and innovative extension of our previous framework for research on work and obesity in professional firefighters [26]. Our previous theoretical framework was developed for research on work and obesity in professional firefighters who are mostly male and mostly white in a suburban county of Southern California. Our previous theoretical framework has successfully guided a research project (called the FORWARD study) that has shed new light on the inter-relations between working conditions, health-related behaviors, obesity, and CVD risk factors among professional firefighters $[116,164,165]$.

Nonetheless, our previous theoretical framework is limited in application to research on work and obesity in urban transit operators due to the following reasons. First, the work/rest schedule of transit operators is largely regulated by the FMCSA federal (national) regulation, while the work shift schedule of professional firefighters is determined through collective bargaining between the local fire department and local firefighter union. This observation led us to consider theoretically a broader socioecological perspective, including both the macro-level (national polices and regulations) and micro-level (worksite) contexts which is more consistent with the aforementioned multi-level socioecological health promotion models [29-31]. Our previous theoretical framework was exclusively centered on local worksite contexts and lacked macro-level (national or societal) contexts. Second, bus drivers, as contrasted with firefighters and workers in other occupations, have unique working conditions, that of driving a bus, that place them in situations requiring continuous vigilance contributing to chronic arousal. Third, there is a substantial obesity disparity between minority women operators and male and other female operators. Our previous theoretical framework developed for research in predominantly white male professional firefighters could not appropriately explain obesity disparity within a single occupational group. This dilemma could be resolved in our new theoretical framework by employing the theory of intersectionality with a focus on the potentially differential experiences of minority women operators not only at the workplace, but also at the residential (community) and society levels. Fourth, obesity and work-related injuries/chronic severe pain are both 
prevalent among some blue collar workers, including transit operators and firefighters. However, as mentioned before, work-related injuries and severe chronic pain were not considered in our previous theoretical framework in professional firefighters. In contrast, our new theoretical framework suggests a possible causal relationship between adverse working conditions, workrelated injuries/chronic pain, and weight gain/obesity in working populations based on an extensive literature review on occupational ergonomics (impact of psychosocial and physical working conditions on work-related injuries and chronic pain), worksite health promotion (health behaviors), and sleep/stress. On the other hand, the work stress model by Gardell and his colleagues [61] was a very helpful platform for us to specify several job demands and resources as occupational risk factors for obesity among urban transit operators.

\section{Implications for future worksite obesity interventions in urban transit operators}

Our new framework has some important implications for future intervention studies for improving the cardiovascular health (e.g., obesity, hypertension, and metabolic syndrome) of urban transit operators. As mentioned before, the previous two 18-month intervention studies $[5,23]$ were not successful in reducing or preventing obesity/BMI increase among transit operators: healthy vending machine choices at division buildings [5] and typical worksite health promotion programs based on health education and individual/group activities [23] were not efficacious. Our new framework points to adverse working conditions as potential "high impact leverage points" [166, 167] for obesity interventions and other CVD risk factor interventions (e.g., high blood pressure) among urban transit operators. Previous worksite environmental interventions for improving weight status have been confined to physical environmental changes such as onsite food availability and onsite exercise facilities [35].

Several successful European intervention studies targeted adverse working conditions of transit operators (bus only lanes, reducing curves on the route, improving information service for the public, installing new driver's seats, work-hour reduction, improving communication, and creating semi-autonomous teams of drivers) [168-172]. The interventions successfully resulted in lowered perceived workload, psychosocial stressors and, in some cases lower CVD risk factors (resting systolic blood pressure and heart rate at work), sickness absenteeism, job dissatisfaction, psychological distress, and body pain. Although none of these successful interventions have examined weight status or obesity as a key intervention outcome, they support that adverse working conditions are changeable for improving the health of transit operators.

Our new framework also clearly indicates that in order to improve the cardiovascular health of transit operators, transit stakeholders in addition to changes in job demands and job resource should also make efforts to address macro-level (national and community) determinants of adverse working conditions and health behaviors of transit operators. For example, the FMCSA hours of service (work and rest) regulation for commercial vehicle drivers has been revised, discussed, and sometimes suspended. A new regulation for reducing fatigue among truck drivers was introduced in 2013. The 34-h restart rule: for a restart, drivers should have at least $34 \mathrm{~h}$ off-duty time after their 60 - or 70 -h work schedule and the 34-h off-duty time should include two periods of 1 am to $5 \mathrm{am}$. However, it has been suspended until the end of an on-going safety and health research project on the new regulation (https:// www.fmcsa.dot.gov/regulations/hours-service/summaryhours-service-regulations). If necessary, a similar regulation may be implemented for transit operators in the future. Transit stakeholders can work together with minority community stakeholders (e.g., community and political leaders, local businesses and organizations, health care providers, and local academic researchers) to create healthy food or exercise environments in minority communities [173-175].

Our hypotheses highlighted above in the new theoretical framework are that some adverse working conditions (long driving and working hours, irregular or alternative shifts, time pressure including short layover time and constant threat avoidance vigilance, conflict with passengers, violence from passengers, prolonged sedentary work, in-vehicle physical/ergonomic hazards, low supervisor and management support, work-andfamily conflict, low accessibility to bathrooms on route, and poor health-related facilities at division buildings), largely characterized as a combination of high demands and low resources, will all and in part increase the risk for weight gain/obesity among transit operators directly through chronic strain and dysfunction of hypothalamic regulation, and indirectly through health-related behaviors at the worksite and during leisure-time as well as through injuries/chronic severe pain. In addition, adiposity risk will be greater in minority women operators due to their greater exposure to adverse occupational and non-occupational conditions.

Our etiological framework and hypotheses on adverse working conditions and obesity risk among transit operators remain to be tested and refined through future observational, intervention, and field biological monitoring (e.g., salivary cortisol and ambulatory heart rate, heart rate variability, and blood pressure) studies. Nonetheless, 
we think that our newly developed framework is a good theoretical guide and will significantly facilitate future transit worksite obesity studies by a joint research team of interdisciplinary university researchers and transit stakeholders. Also, the framework, if confirmed in future studies, will contribute to understanding the complex and important roles of adverse working conditions in the etiology of weight gain/obesity and obesity disparity among transit operators and other working populations.

\section{Abbreviation}

BMI: Body mass index; CVD: Cardiovascular disease; FMCSA: Federal Motor Carrier Safety Administration; FORWARD: Firefighter Obesity Research: Workplace Assessment to Reduce Disease; LACMTA: Los Angeles County Metropolitan Transit Authority; REV-ERBa (known as NR1D1): Nuclear Receptor Subfamily 1, Group D, Member 1; SMART: Sheet Metal Air Rail Transportation; TAV: Threat avoidance vigilance; US: United States

\section{Acknowledgements}

We express our sincere thanks to the Los Angeles County Metropolitan Transit Authority (LACMTA) transit operators for their participation in our pilot study (focus groups and interviews). We also appreciated the strong support of the LACMTA management, the Sheet Metal Air Rail Transportation (SMART) local unions, and the SMART-MTA Trust Fund for the pilot study. The LACMTA and local unions had no decision-making role in the decision to publish study results or the content of the publication. This study is supported by the Centers for Disease Control and Prevention (CDC)/National Institute for Occupational Safety and Health (NIOSH) through Southern California NIOSH Education and Research Center: Pilot Project Program: Grant \#: T42OH008412.

\section{Funding}

This study is supported by the Centers for Disease Control and Prevention (CDC)/National Institute for Occupational Safety and Health (NIOSH) through Southern California NIOSH Education and Research Center: Pilot Project Program: Grant \#: T42OH008412. Its contents are solely the responsibility of the authors and do not necessarily represent the official views of the CDC/NIOSH.

\section{Availability of data and material}

Not applicable.

\section{Authors' contributions}

All authors meet the authorship described as recommended by the ICJME: All authors made substantial contributions to the design of this study and acquisition, analysis, or interpretation of data for the work. BC conceived and drafted this manuscript. PS, MD, HY, DB, and YS made contributions to the acquisition, analysis, or interpretation of data. All coauthors revised the manuscript critically. All authors read and approved the final manuscript and agreed to be accountable for all aspects of the work in ensuring that questions related to the accuracy or integrity of any part of the work are appropriately investigated and resolved.

\section{Competing interests}

The authors declare that they have no competing interest.

\section{Consent for publication}

Not applicable.

\section{Ethics approval and consent to participate}

The study design and protocol were approved by the Institutional Review Board (IRB) of University of California Irvine. All of the transit operators who participated in our pilot study provided written informed consent.

\section{Publisher's Note}

Springer Nature remains neutral with regard to jurisdictional claims in published maps and institutional affiliations.

\section{Author details}

${ }^{1}$ Center for Occupational and Environmental Health, University of California Irvine, 100 Theory, Suite 100, Irvine, CA 92617, USA. ²Department of Sociology, University of Massachusetts Amherst, 200 Hicks Way, Amherst, MA 01003, USA.

Received: 27 March 2017 Accepted: 10 May 2017

Published online: 17 May 2017

\section{References}

1. Gillespie RM, Wang X, Brown T. Developing best-practice guidelines for improving bus operator health and retention. 2016. http://onlinepubs.trb. org/onlinepubs/tcrp/tcrp_rpt_169.pdf. Accessed 16 June 2016.

2. Bureau of Labor Statistics (US Department of Labor). Bus drivers. http:// www.bls.gov/ooh/transportation-and-material-moving/bus-drivers.htm. Accessed 16 June 2016.

3. National Occupational Research Agenda (NORA)Transportation, Warehousing, and Utilities Sector Council. National Transportation, Warehousing, and Utilities Agenda; 2009. https:/www.cdc.gov/niosh/nora/ comment/agendas/transwareutil/pdfs/TransWareUtilAug2009.pdf. Accessed 10 Feb 2016.

4. Carban-Martinez AJ, Lee DJ, Fleming LE, Gomez O, LeBlanc W, Pitman T. Obesity in US workers: the national health interview survey, 1986 to 2002. Am J Public Health. 2005;95(9):1-9.

5. French SA, Harnack LJ, Hannan PJ, Mitchell NR, Gerlach AF, Toomey TL. Worksite environment intervention to prevent obesity among metropolitan transit workers. Prev Med. 2010;50(4):180-5.

6. Harvey SB, Glozier N, Carlton O, Mykletun A, Henderson M, Hotopf M, Holland-Elliott K. Obesity and sickness absence: results from the CHAP study. Occup Med. 2010;60(5):362-8.

7. Thiese MS, Moffitt G, Hanowski RJ, Kales SN, Porter RJ, Hegmann KT. Commercial driver medical examinations: prevalence of obesity, comorbidities, and certification outcomes. J Occup Environ Med. 2015;57(6): 659-65.

8. Rosengren A, Anderson K, Wilhelmsen L. Risk of coronary heart disease in middle-aged male bus and tram drivers compared to men in other occupations: a prospective study. Int J Epidemiol. 1991;20(1):82-7.

9. Gu JK, Charles LE, Bang KM, Ma CC, Andrew ME, Violanti JM, Burchfiel CM. Prevalence of obesity by occupation among US workers: the National Health Interview Survey 2004-2011. J Occup Environ Med. 2014;56(5):516-28.

10. Benavides FG, Benach J, Mira M, Sáez M, Barceló A. Occupational categories and sickness absence certified as attributable to common diseases. Eur J Public Health. 2003;13(1):51-5.

11. Bigert C, Gustavsson P, Hallqvist J, Hogstedt C, Lewné M, Plato N, Reuterwall C, Schéele P. Myocardial infarction among professional drivers. Epidemiology. 2003;14(3):333-9.

12. Tse JLM, Flin R, Mearns K. Bus driver well-being review: 50 years of research. Transp Res F. 2006:9(2):89-114.

13. Tüchsen F, Bach E, Marmot M. Occupation and hospitalization with ischaemic heart diseases: a new nationwide surveillance system based on hospital admissions. Int J Epidemiol. 1992;21(3):450-9.

14. Winkleby MA, Ragland DR, Syme SL. Self-reported stressors and hypertension: evidence of an inverse association. Am J Epidemiol. 1988; 127(1):124-34.

15. Witters D. U.S. Doctors Lead in Wellbeing, Transportation Workers Lag http://www.gallup.com/poll/161324/physicians-lead-wellbeingtransportation-workers-lag.aspx. Accessed 16 June 2016.

16. Krause N, Ragland DR, Greiner BA, Fisher JM, Holman BL, Selvin S. Physical workload and ergonomic factors associated with prevalence of back and neck pain in urban transit operators. Spine. 1997;22(18):211726.

17. Krause N, Rugulies R, Ragland DR, Syme SL. Physical workload, ergonomic problems, and incidence of low back injury: a 7.5-year prospective study of San Francisco transit operators. Am J Ind Med. 2004;46(6):570-85.

18. Bushnell PT, Li J, Landen D. Group medical claims as a source of information on worker health and potentially work-related diseases. J Occup Environ Med. 2011;53(12):1430-41.

19. Wei C. Incidence of and risk factors for occupational injury among transit bus operators. 2014. http://conservancy.umn.edu/bitstream/handle/11299/ 163927/Wei_umn_0130E_14863.pdf? sequence=1\&isAllowed=y. Accessed 16 June 2016. 
20. Ebrahimi MH, Delvarianzadeh M, Saadat S. Prevalence of metabolic syndrome among Iranian occupational drivers. Diabetes Metab Syndr. 2016; 10(1 Suppl 1):S46-51.

21. Shin SY, Lee CG, Song HS, Kim SH, Lee HS, Jung MS, Yoo SK. Cardiovascular disease risk of bus drivers in a city of Korea. Ann Occup Environ Med. 2013; 25(1):34.

22. Escoto KH, French SA, Harnack L, Toomey TL, Hannan PJ, Mitchell NR. Work hours, weight status, and weight-related behaviors: a study of metro transit workers. Int J Behav Nutr Phys Act. 2010;20;7:91.

23. Hedberg GE, Wikström-Frisén L, Janlert U. Comparison between two programmes for reducing the levels of risk indicators of heart diseases among male professional drivers. Occup Environ Med. 1998;55(8):554-61.

24. Ragland DR, Krause N, Greiner BA, Fisher JM. Studies of health outcomes in transit operators: policy implications of the current scientific database. J Occup Health Psychol. 1998;3(2):172-87.

25. Pandalai SP, Schulte PA, Miller DB. Conceptual heuristic models of the interrelationships between obesity and the occupational environment. Scand J Work Environ Health. 2013;39(3):221-32.

26. Choi $B$, Schnall $P$, Dobson $M$, Israel $L$, Landsbergis $P$, Galassetti $P$, Pontello A, Kojaku S, Baker D. Exploring occupational and behavioral risk factors for obesity in firefighters: a theoretical framework and study design. Saf Health Work. 2011;2(4):301-12.

27. Anderson R. The back pain of bus drivers. Prevalence in an urban area of California. Spine. 1992;17(12):1481-8.

28. Edberg M. Essentials of health behavior: social and behavioral theory in public health. Jones \& Bartlett Learning, LLC: Sudbury; 2007.

29. Glass TA, McAtee MJ. Behavioral science at the crossroads in public health: extending horizons, envisioning the future. Soc Sci Med. 2006;62(7):1650-71.

30. McLeroy KR, Bibeau D, Steckler A, Glanz K. An ecological perspective on health promotion programs. Health Educ Q. 1988;15(4):351-77.

31. Schneider M, Stokols D. Multilevel theories of behavior change: a social ecological framework. In: Shumaker SA, Ockene JK, Riekert KA, editors. The handbook of health behavior change. 3rd ed. New York: Springer Publishing Company; 2009. p. 85-105.

32. Dobson M, Choi B, Schnall P, Garcia J, Seo Y. Exploring occupational and health behavioral factors in obesity and health among bus operators: a qualitative study. Presented at the 2015 APA/NIOSH Work Stress, and Health conference, 6-9 May 2015, Atlanta, United States.

33. Ng MK, Yousuf B, Bigelow PL, Van Eerd D. Effectiveness of health promotion programmes for truck drivers: a systematic review. Health Educ J. 2015;74(3): 270-86.

34. Apostolopoulos Y, Sönmez S, Shattell M, Haldeman L, Strack R, Jones V. Barriers to truck drivers' healthy eating: environmental influences and health promotion strategies. J Workp Behav Health. 2011;26(2):122-43.

35. Anderson LM, Quinn TA, Glanz K, Ramirez G, Kahwati LC, Johnson DB, Buchanan LR, Archer WR, Chattopadhyay S, Kalra GP, Katz DL, Task Force on Community Preventive Services. The effectiveness of worksite nutrition and physical activity interventions for controlling employee overweight and obesity: a systematic review. Am J Prev Med. 2009;37(4):340-57.

36. Verweij LM, Coffeng J, van Mechelen W, Proper Kl. Meta-analyses of workplace physical activity and dietary behaviour interventions on weight outcomes. Obes Rev. 2011;12(6):406-29.

37. Feltner C, Peterson K, Weber RP, Cluff L, Coker-Schwimmer E, Viswanathan M, Lohr KN. The effectiveness of Total Worker Health interventions: a systematic review for a National Institutes of Health pathways to prevention workshop. Ann Intern Med. 2016;165(4):262-9.

38. Wong JY, Gilson ND, Bush RA, Brown WJ. Patterns and perceptions of physical activity and sedentary time in male transport drivers working in regional Australia. Aust N Z J Public Health. 2014;38(4):314-20.

39. van Drongelen A, Boot CR, Merkus SL, Smid T, van der Beek AJ. The effects of shift work on body weight change - a systematic review of longitudinal studies. Scand J Work Environ Health. 2011;37(4):263-75.

40. Solovieva S, Lallukka T, Virtanen M, Viikari-Juntura E. Psychosocial factors at work, long work hours, and obesity: a systematic review. Scand J Work Environ Health. 2013;39(3):241-58

41. Morikawa $Y$, Nakagawa $H$, Miura K, Soyama $Y$, Ishizaki M, Kido T, Naruse $Y$, Suwazono $Y$, Nogawa K. Effect of shift work on body mass index and metabolic parameters. Scand J Work Environ Health. 2007:33:45-50.

42. Suwazono Y, Dochi M, Sakata K, Okubo Y, Oishi M, Tanaka K, Kobayashi E, Kido T, Nogawa K. A longitudinal study on the effect of shift work on weight gain in male Japanese workers. Obesity. 2008;16(8):1887-93.
43. van Amelsvoort LG, Schouten EG, Kok FJ. Duration of shiftwork related to body mass index and waist to hip ratio. Int J Obes Relat Metab Disord. 1999;23:973-8.

44. Au N, Hauck K, Hollingsworth B. Employment, work hours and weight gain among middle-aged women. Int J Obes. 2013;37(5):718-24.

45. Mercan MA. A research note on the relationship between long working hours and weight gain for older workers in the United States. Res Aging. 2014;36(5):557-67.

46. Nakamura K, Shimai S, Kikuchi S, Takahashi H, Tanaka M, Nakano S, et al. Increases in body mass index and waist circumference as outcomes of working overtime. Occup Med. 1998;48:169-73.

47. Shields M. Long working hours and health. Health Rep. 1999;11:33-48.

48. Eriksen D, Rosthøj S, Burr H, Holtermann A. Sedentary work-associations between five-year changes in occupational sitting time and body mass index. Prev Med. 2015;73:1-5.

49. Lin TC, Courtney TK, Lombardi DA, Verma SK. Association between sedentary work and BMI in a U.S. national longitudinal survey. Am J Prev Med. 2015;49(6):e117-23.

50. Picavet HS, Pas LW, van Oostrom SH, van der Ploeg HP, Verschuren WM, Proper KI. The relation between occupational sitting and mental, cardiometabolic, and musculoskeletal health over a period of 15 years-the Doetinchem cohort study. PLoS One. 2016;11(1):e0146639.

51. Pinto Pereira SM, Power C. Sedentary behaviours in mid-adulthood and subsequent body mass index. PLoS One. 2013;8(6):e65791.

52. Pulsford RM, Stamatakis E, Britton AR, Brunner EJ, Hillsdon MM. Sitting behavior and obesity: evidence from the Whitehall II study. Am J Prev Med. 2013;44(2):132-38.

53. Choi B, Schnall P, Dobson M, Yang H, Landsbergis P, Baker D. Job control and job demands as risk factors for central obesity in US workers: a 9year follow-up study. Presented at the 4th International Congress of Occupational Health on Psychosocial Factors at Work, June 14-17 2010, Amsterdam, the Netherlands.

54. Block JP, He Y, Zaslavsky AM, Ding L, Ayanian JZ. Psychosocial stress and change in weight among US adults. Am J Epidemiol. 2009;170: 181-92.

55. Ishizaki M, Nakagawa H, Morikawa Y, Honda R, Yamada Y, Kawakami N, Japan Work Stress and Health Cohort Study Group. Influence of job strain on changes in body mass index and waist circumference-6-year longitudinal study. Scand J Work Environ Health. 2008;34:288-96.

56. Gram Quist H, Christensen U, Christensen KB, Aust B, Borg V, Bjorner JB. Psychosocial work environment factors and weight change: a prospective study among Danish health care workers. BMC Public Health. 2013;13:43.

57. Choi B, Dobson M, Landsbergis P, Ko SB, Yang H, Schnall P, Baker D. Job strain and obesity. J Intern Med. 2014;275(4):438-40.

58. Fujishiro K, Lawson CC, Hibert EL, Chavarro JE, Rich-Edwards JW. Job strain and changes in the body mass index among working women: a prospective study. Int J Obes. 2015;39(9):1395-400.

59. Nyberg ST, Heikkilä K, Fransson El, Alfredsson L, De Bacquer D, Bjorner JB, Bonenfant S, Borritz M, Burr H, Casini A, Clays E, Dragano N, Erbel R, Geuskens GA, Goldberg M, Hooftman WE, Houtman IL, Jöckel KH, Kittel F, Knutsson A, Koskenvuo M, Leineweber C, Lunau T, Madsen IE, Hanson LL, Marmot MG, Nielsen ML, Nordin M, Oksanen T, Pentti J, Rugulies R, Siegrist J, Suominen S, Vahtera J, Virtanen M, Westerholm P, Westerlund H, Zins M, Ferrie JE, Theorell T, Steptoe A, Hamer M, Singh-Manoux A, Batty GD, Kivimäki M, IPD-Work Consortium. Job strain in relation to body mass index: pooled analysis of 160000 adults from 13 cohort studies. J Intern Med. 2012;272(1):65-73.

60. Brunner EJ, Chandola T, Marmot MG. Prospective effect of job strain on general and central obesity in the Whitehall II Study. Am J Epidemiol. 2007;165:828-37.

61. Gardell B, Aronsson G, Barklöf K. The working environment for local public transport personnel. 1982.

62. Gupta D, Li F, Wilson N. Extraboard-driver workforce planning for bus transit operations. http://www.isye.umn.edu/labs/scorlab/pdf/GLW11.pdf. Accessed 28 Feb 2017.

63. Duffy CA, McGoldrick AE. Stress and the bus driver in the UK transport industry. Work Stress. 1990;4(1):17-27.

64. Wetzel T. Opposition Movement in Los Angeles Transit Union. 2006. http://www.uncanny.net/ wetzel/LAtransitunionopposition.htm. Accessed 16 June 2016. 
65. Belkić K, Savić C, Theorell T, Rakić L, Ercegovac D, Djordjević M. Mechanisms of cardiac risk among professional drivers. Scand J Work Environ Health. 1994;20(2):73-86.

66. Karasek RA. Job demands, job decision latitude, and mental strain: implications for job redesign. Admin Sci Quart. 1979;24:285-308.

67. Meijman TF, Kompier MA. Bussy business: how urban bus drivers cope with time pressure, passengers, and traffic safety. J Occup Health Psychol. 1998; 3(2):109-21.

68. Biggs $H$, Dingsdag D, Stenson N. Fatigue factors affecting metropolitan bus drivers: A qualitative investigation. Work. 2009;32(1):5-10.

69. Hege A, Apostolopoulos Y, Perko M, Sönmez S, Strack R. The work organization of long-haul truck drivers and the association with body mass index. J Occup Environ Med. 2016;58(7):712-7.

70. Rosso GL, Perotto M, Feola M, Bruno G, Caramella M. Investigating obesity among professional drivers: the high risk professional driver study. Am J Ind Med. 2015;58(2):212-9.

71. Gimeno D, Benavides FG, Mira M, Martinez JM, Benach J. External validation of psychological job demands in a bus driver sample. J Occup Health. 2004; 46(1):43-8.

72. Greiner BA, Krause N, Ragland DR, Fisher JM. Objective stress factors, accidents, and absenteeism in transit operators: a theoretical framework and empirical evidence. J Occup Health Psychol. 1998;3(2):130-46.

73. Varela-Mato V, Yates T, Stensel DJ, Biddle SJ, Clemes SA. Time spent sitting during and outside working hours in bus drivers: a pilot study. Prev Med Rep. 2015;3:36-9.

74. Mackechnie C. Transit 101: extra board operators. http://publictransport. about.com/od/Transit_Employment/a/Transit-101-Extra-Board-Operators. htm. Accessed 16 June 2016.

75. Björntorp P. The regulation of adipose tissue distribution in humans. Int J Obes Relat Metab Disord. 1996:20:291-302.

76. Rosmond R, Björntorp P. Psychosocial and socio-economic factors in women and their relationship to obesity and regional body fat distribution. Int J Obes Relat Metab Disord. 1999;23:138-45.

77. Björntorp P. Do stress reactions cause abdominal obesity and comorbidities? Obes Rev. 2001;2:73-86.

78. Burke HM, Davis MC, Otte C, Mohr DC. Depression and cortisol responses to psychological stress: a meta-analysis. Psychoneuroendocrinology. 2005;30(9): 846-56.

79. Dodt C, Lönnroth P, Wellhöner JP, Fehm HL, Elam M. Sympathetic control of white adipose tissue in lean and obese humans. Acta Physiol Scand. 2003; 177:351-7.

80. Kapit W, Macey Rl, Meisami E. The physiology coloring book. 2nd ed. Benjamin Cummings: San Francisco; 1999.

81. Knutson KL, Spiegel K, Penev P, Van Cauter E. The metabolic consequences of sleep deprivation. Sleep Med Rev. 2007;11:163-78.

82. Plotsky PM, Cunningham Jr ET, Widmaier EP. Catecholaminergic modulation of corticotropin-releasing factor and adrenocorticotropin secretion. Endocr Rev. 1989;10:437-58.

83. Pratt LA, Brody DJ. Depression and obesity in the US adult household population, 2005-2010. Women. 2014;20:39.

84. Pasquali R, Vicennati V, Gambineri A, Pagotto U. Sex-dependent role of glucocorticoids and androgens in the pathophysiology of human obesity. Int J Obes. 2008:32(12):1764-79.

85. Bose M, Oliván B, Laferrère B. Stress and obesity: the role of the hypothalamic-pituitary-adrenal axis in metabolic disease. Curr Opin Endocrinol Diabetes Obes. 2009;16(5):340-6.

86. Vicennati V, Pasqui F, Cavazza C, Pagotto U, Pasquali R. Stress-related development of obesity and cortisol in women. Obesity. 2009;17(9):1678-83.

87. Huang W, Ramsey KM, Marcheva B, Bass J. Circadian rhythms, sleep, and metabolism. J Clin Invest. 2011;121(6):2133-41.

88. Campbell JE, Peckett AJ, D'souza AM, Hawke TJ, Riddell MC. Adipogenic and lipolytic effects of chronic glucocorticoid exposure. Am J Physiol Cell Physiol. 2011;300(1):C198-209.

89. Froy O. Metabolism and circadian rhythms-implications for obesity. Endocr Rev. 2010;31(1):1-24

90. Bakopanos E, Silva JE. Opposing effects of glucocorticoids on beta(3)adrenergic receptor expression in HIB-1B brown adipocytes. Mol Cell Endocrinol. 2002;190(1-2):29-37.

91. Collins S, Surwit RS. The beta-adrenergic receptors and the control of adipose tissue metabolism and thermogenesis. Recent Prog Horm Res. 2001;56:309-28.
92. Cypess AM, Weiner LS, Roberts-Toler C, Franquet Elía E, Kessler SH, Kahn PA, English J, Chatman K, Trauger SA, Doria A, Kolodny GM. Activation of human brown adipose tissue by a $\beta 3$-adrenergic receptor agonist. Cell Metab. 2015;21(1):33-8.

93. Himms-Hagen J. Brown adipose tissue thermogenesis and obesity. Prog Lipid Res. 1989;28(2):67-115.

94. Lowell BB, Flier JS. Brown adipose tissue, beta 3-adrenergic receptors, and obesity. Annu Rev Med. 1997;48:307-16.

95. Louis SN, Jackman GP, Nero TL, lakovidis D, Louis WJ. Role of betaadrenergic receptor subtypes in lipolysis. Cardiovasc Drugs Ther. 2000;14(6): 565-77.

96. Sharma AM, Pischon T, Hardt S, Kunz I, Luft FC. Hypothesis: beta-adrenergic receptor blockers and weight gain: a systematic analysis. Hypertension. 2001;37(2):250-4.

97. Fenzl A, Kiefer FW. Brown adipose tissue and thermogenesis. Horm Mol Biol Clin Investig. 2014;19(1):25-37.

98. Delezie J, Challet E. Interactions between metabolism and circadian clocks: reciprocal disturbances. Ann N Y Acad Sci. 2011;1243:30-46.

99. Langendonk JG, Pijl H, Toornvliet AC, Burggraaf J, Frölich M, Schoemaker RC, Doornbos J, Cohen AF, Meinders AE. Circadian rhythm of plasma leptin levels in upper and lower body obese women: influence of body fat distribution and weight loss. J Clin Endocrinol Metab. 1998;83(5):1706-12.

100. Spiegel K, Leproult R, Van Cauter E. Impact of sleep debt on physiological rhythms. Rev Neurol (Paris). 2003;159(11 Suppl)):6S11-20.

101. Arble DM, Bass J, Laposky AD, Vitaterna MH, Turek FW. Circadian timing of food intake contributes to weight gain. Obesity (Silver Spring). 2009;17(11): 2100-2.

102. Delezie J, Dumont S, Dardente H, Oudart H, Gréchez-Cassiau A, Klosen P, Teboul M, Delaunay F, Pévet $P$, Challet $E$. The nuclear receptor REV-ERBa is required for the daily balance of carbohydrate and lipid metabolism. FASEB J. 2012;26(8):3321-35.

103. Mauck Jr HP, Hoff EC. Experimental neurogenic arrhythmias. Bull N Y Acad Med. 1967:43(12):1097-105.

104. Simonson E, Baker C, Burns N, Keiper C, Schmitt OH, Stackhouse S. Cardiovascular stress (electrocardiographic changes) produced by driving an automobile. Am Heart J. 1968;75(1):125-35.

105. Pop C, Manea V, Matei C, Trambitasu R, Mos L. Work stress hypertension and obesity among professional bus drivers: results of a cross-sectional study conducted in an urban Romanian company of transport. J Hypertens Res. 2015;1:27-32

106. Tawakol A, Ishai A, Takx RA, Figueroa AL, Ali A, Kaiser Y, Truong QA, Solomon CJ, Calcagno C, Mani V, Tang CY, Mulder WJ, Murrough JW, Hoffmann U, Nahrendorf M, Shin LM, Fayad ZA, Pitman RK. Relation between resting amygdalar activity and cardiovascular events: a longitudinal and cohort study. Lancet. 2017. doi: 10.1016/S01406736(16)31714-7.

107. Choi $B$, Schnall $P$, Yang $H$, Dobson M, Landsbergis $P$, Israel L, Karasek R, Baker D. Psychosocial working conditions and active leisure-time physical activity in middle-aged US workers. Int J Occup Med Environ Health. 2010; 23(3):239-53.

108. Nishitani N, Sakakibara H, Akiyama I. Eating behavior related to obesity and job stress in male Japanese workers. Nutrition. 2009;25:45-50.

109. Atkinson G, Fullick S, Grindey C, Maclaren D. Exercise, energy balance and the shift worker. Sports Med. 2008;38:671-85.

110. Devine CM, Farrell TJ, Blake CE, Jastran M, Wethington E, Bisogni CA. Work conditions and the food choice coping strategies of employed parents. J Nutr Educ Behav. 2009:41:365-70.

111. Morikawa Y, Miura K, Sasaki S, Yoshita K, Yoneyama S, Sakurai M, Ishizaki M, Kido T, Naruse Y, Suwazono Y, Higashiyama M, Nakagawa H. Evaluation of the effects of shift work on nutrient intake: a cross-sectional study. J Occup Health. 2008;50:270-8.

112. Brisson C, Larocque B, Moisan J, Vézina M, Dagenais GR. Psychosocial factors at work, smoking, sedentary behavior, and body mass index: a prevalence study among 6995 white collar workers. J Occup Environ Med. 2000:42:406.

113. Kouvonen A, Kivimäki $M$, Elovainio $M$, Pentti J, Linna A, Virtanen $M$, Vahtera J. Effort/reward imbalance and sedentary lifestyle: an observational study in a large occupational cohort. Occup Environ Med. 2006;63:422-7.

114. Schneider S, Becker S. Prevalence of physical activity among the working population and correlation with work-related factors: results from the first German National Health Survey. J Occup Health. 2005;47:414-23. 
115. Fransson El, et al. Job strain as a risk factor for leisure-time physical inactivity: an individual-participant meta-analysis of up to 170,000 men and women: the IPD-Work Consortium. Am J Epidemiol. 2012;176(12): 1078-89.

116. Choi B, Dobson M, Schnall P, Garcia-Rivas J. 24-h work shifts, sedentary work, and obesity in male firefighters. Am J Ind Med. 2016:59(6):486-500.

117. Choi B, Schnall P, Yang H, Dobson M, Landsbergis P, Israel L, Karasek R, Baker D. Sedentary work, low physical job demand, and obesity in US workers. Am J Ind Med. 2010;53(11):1088-101.

118. Church TS, Thomas DM, Tudor-Locke C, Katzmarzyk PT, Earnest CP, Rodarte RQ, Martin CK, Blair SN, Bouchard C. Trends over 5 decades in U.S. occupation-related physical activity and their associations with obesity. PLoS One. 2011:6(5):e19657.

119. Szeto GP, Lam P. Work-related musculoskeletal disorders in urban bus drivers of Hong Kong. J Occup Rehabil. 2007;17(2):181-98.

120. Nobrega S, Champagne N, Abreu M, Goldstein-Gelb M, Montano M, Lopez I, Arevalo J, Bruce S, Punnett L. Obesity/overweight and the role of working conditions: a qualitative, participatory investigation. Health Promot Pract. 2016;17(1):127-36.

121. Canivet C, Ostergren PO, Choi B, Nilsson P, Af Sillén U, Moghadassi M, Karasek R, Isacsson SO. Sleeping problems as a risk factor for subsequent musculoskeletal pain and the role of job strain: results from a one-year follow-up of the Malmö Shoulder Neck Study Cohort. Int J Behav Med. 2008;15(4):254-62

122. Phillips KM, Clark ME, Gironda RJ, McGarity S, Kerns RW, Elnitsky CA Andresen EM, Collins RC. Pain and psychiatric comorbidities among two groups of Iraq and Afghanistan era Veterans. J Rehabil Res Dev. 2016; 53(4):413-32.

123. Sivertsen B, Lallukka T, Petrie KJ, Steingrímsdóttir ÓA, Stubhaug A, Nielsen CS. Sleep and pain sensitivity in adults. Pain. 2015;156(8):1433-9.

124. Jahnke SA, Poston WS, Haddock CK, Jitnarin N. Obesity and incident injury among career firefighters in the central United States. Obesity. 2013;21(8): 1505-08.

125. Poplin GS, Roe DJ, Peate W, Harris RB, Burgess JL. The association of aerobic fitness with injuries in the fire service. Am J Epidemiol. 2014;179(2):149-55.

126. Crenshaw K. Demarginalizing the intersection of race and sex: A black feminist critique of antidiscrimination doctrine, feminist theory and antiracist politics. U. Chi. Legal F. 1989:139. http://chicagounbound.uchicago. edu/cgi/viewcontent.cgi?article=1052\&context=uclf. Accessed 16 June 2016.

127. Bauer GR. Incorporating intersectionality theory into population health research methodology: challenges and the potential to advance health equity. Soc Sci Med. 2014;110:10-7.

128. Bowleg $L$. The problem with the phrase women and minorities: intersectionality-an important theoretical framework for public health. Am J Public Health. 2012;102(7):1267-73.

129. Aronsson G, Rissler A. Psychophysiological stress reactions in female and male urban bus drivers. J Occup Health Psychol. 1998;3(2):122-9.

130. Artazcoz L, Cortès I, Borrell C, Escribà-Agüir V, Cascant L. Gender perspective in the analysis of the relationship between long workhours, health and health-related behavior. Scand J Work Environ Health. 2007;33(5):344-50.

131. Aguirre-Molina M, Molina CW. Ethnic/racial populations and worksite health promotion. Occup Med. 1990;5(4):789.

132. Gordon-Larsen P, Nelson MC, Page P, Popkin BM. Inequality in the built environment underlies key health disparities in physical activity and obesity. Pediatrics. 2006;117(2):417-24.

133. Lovasi GS, Hutson MA, Guerra M, Neckerman KM. Built environments and obesity in disadvantaged populations. Epidemiol Rev. 2009;31:7-20.

134. Krieger N, Rowley DL, Herman AA, Avery B, Phillips MT. Racism, sexism, and social class: implications for studies of health, disease, and well-being. Am J Prev Med. 1993:9(6 Suppl):82-122

135. Clark R, Anderson NB, Clark VR, Williams DR. Racism as a stressor for African Americans. A biopsychosocial model. Am Psychol. 1999:54(10):805-16.

136. Choi B, Schnall P, Yang H, Dobson M, Landsbergis P, Israel L, Karasek R, Baker D. Work stress and overeating coping in the US workforce. Int J Occup Med Environ Health. 2009;22(Suppl):43

137. Allan JD. Explanatory models of overweight among African American, Euro-American, and Mexican American women. West J Nurs Res. 1998; 20(1):45-66.

138. Fitzgibbon ML, Blackman LR, Avellone ME. The relationship between body image discrepancy and body mass index across ethnic groups. Obes Res. 2000;8(8):582-9.
139. Cachelin FM, Rebeck RM, Chung GH, Pelayo E. Does ethnicity influence body-size preference? A comparison of body image and body size. Obes Res. 2002;10(3):158-66.

140. Lopez E, Blix GG, Blix AG. Body image of Latinas compared to body image of non-Latina White women. Health Values. 1995;19(6):3-10.

141. Airhihenbuwa CO, Kumanyika S, Agurs TD, Lowe A. Perceptions and beliefs about exercise, rest, and health among African-Americans. Am J Health Promot. 1995;9(6):426-9.

142. Karasek RA, Gordon G, Pietrokovsky C, Frese M, Pieper C, Schwartz J, et al. Job content questionnaire and user's guide. Los Angeles, Lowell: University of Southern California/University of Massachusetts; 1985.

143. Evans GW. Working on the hot seat: urban bus operators. Accid Anal and Prev. 1994:26(2):181-93.

144. Belkic K, Savic C. The occupational stress index-An approach derived from cognitive ergonomics applicable to clinical practice. Scand J Work Environ Health. 2008;6(Suppl):169-76.

145. Shimotsu ST, French SA, Gerlach AF, Hannan PJ. Worksite environment physical activity and healthy food choices: measurement of the worksite food and physical activity environment at four metropolitan bus garages. Int J Behav Nutr Phys Act. 2007;4:17.

146. Cunningham TJ, Berkman LF, Kawachi I, Jacobs Jr DR, Seeman TE, Kiefe Cl, Gortmaker SL. Changes in waist circumference and body mass index in the US CARDIA cohort: fixed-effects associations with self-reported experiences of racial/ethnic discrimination. J Biosoc Sci. 2013;45(2):267-78.

147. Krieger N, Smith K, Naishadham D, Hartman C, Barbeau EM. Experiences of discrimination: validity and reliability of a self-report measure for population health research on racism and health. Soc Sci Med. 2005;61(7):1576-96.

148. Paradies $Y$. A systematic review of empirical research on self-reported racism and health. Int J Epidemiol. 2006;35(4):888-901.

149. French SA, Harnack LJ, Toomey TL, Hannan PJ. Association between body weight, physical activity and food choices among metropolitan transit workers. Int J Behav Nutr Phys Act. 2007:4:52.

150. Van Strien T, Frijters JE, Bergers G, Defares PB. The Dutch Eating Behavior Questionnaire (DEBQ) for assessment of restrained, emotional, and external eating behavior. Int J Eat Disord. 1986;5(2):295-315.

151. Escoto KH, French SA. Unhealthy and healthy weight control behaviours among bus operators. Occup Med. 2012;62(2):138-40.

152. Kuorinka I, Jonsson B, Kilbom A, Vinterberg $H$, Biering-Sørensen $F$, Andersson G, Jørgensen K. Standardised Nordic questionnaires for the analysis of musculoskeletal symptoms. Appl Ergon. 1987;18(3):233-7.

153. Roos E, Laaksonen M, Rahkonen O, Lahelma E, Lallukka T. Weight change and sickness absence-a prospective study among middle-aged employees. Eur J Public Health. 2015;25(2):263-7.

154. Kristensen TS. Sickness absence and work strain among Danish slaughterhouse workers: an analysis of absence from work regarded as coping behaviour. Soc Sci Med. 1991;32(1):15-27.

155. Mujahid MS, Diez Roux AV, Morenoff JD, Raghunathan T. Assessing the measurement properties of neighborhood scales: from psychometrics to ecometrics. Am J Epidemiol. 2007;165(8):858-67.

156. Gutek BA, Searle S, Klepa L. Rational versus gender role explanations for work-family conflict. J Appl Psychol. 1991;76(4):560-68.

157. Ford ES, Mokdad AH, Giles WH. Trends in waist circumference among US adults. Obes Res. 2003;11:1223-31.

158. Lee K, Song YM, Sung J. Which obesity indicators are better predictors of metabolic risk? Healthy twin study. Obesity. 2008;16:834-40.

159. Vazquez G, Duval S, Jacobs Jr DR, Silventoinen K. Comparison of body mass index, waist circumference, and waist/hip ratio in predicting incident diabetes: A meta-analysis. Epidemiol Rev. 2007;29:115-28.

160. Deurenberg P, Yap M, van Staveren WA. Body mass index and percent body fat: a meta analysis among different ethnic groups. Int J Obes Relat Metab Disord. 1998;22:1164-71.

161. Jackson AS, Stanforth PR, Gagnon J, Rankinen T, Leon AS, Rao DC, Skinner $J S$, Bouchard C, Wilmore JH. The effect of sex, age and race on estimating percentage body fat from body mass index: The Heritage Family Study. Int Obes Relat Metab Disord. 2002;26:789-96.

162. Prentice AM, Jebb SA. Beyond body mass index. Obes Rev. 2001;2:141-7.

163. World Health Organization (WHO). Obesity: Preventing and managing the global epidemic. Geneva: WHO; 2000.

164. Dobson M, Choi B, Schnall PL, Wigger E, Garcia-Rivas J, Israel L, Baker DB. Exploring occupational and health behavioral causes of firefighter obesity: a qualitative study. Am J Ind Med. 2013;56(7):776-90. 
165. Choi B, Schnall P, Dobson M. Twenty-four-hour work shifts, increased job demands, and elevated blood pressure in professional firefighters. Int Arch Occup Environ Health. 2016;89(7):1111-25.

166. Stokols D. Establishing and maintaining healthy environments: toward a social ecology of health promotion. Am Psychol. 1992;47(1):6-22.

167. Stokols D. Translating social ecological theory into guidelines for community health promotion. Am J Health Promot. 1996;10(4):282-98.

168. Rydstedt LW, Johansson G, Evans GW. The human side of the road: improving the working conditions of urban bus drivers. J Occup Health Psychol. 1998;3(2):161-71.

169. Evans GW, Johansson G, Rydstedt L. Hassles on the job: a study of a job intervention with urban bus drivers. J Organ Behav. 1999;20(2):199-208.

170. Poulsen K, Jensen S, Bach E, Schostak J. Using action research to improve health and the work environment for 3500 municipal bus drivers. Educ Action Res. 2007:15(1):75-106.

171. Kompier MAJ, Aust B, van den Berg A-M, Siegrist J. Stress prevention in bus drivers: evaluation of 13 natural experiments. J Occup Health Psychol. 2000; 5(1):11-31.

172. Netterstrøm B. Denmark: self-rule on route 166. In: Preventing stress, improving productivity: European case studies in the workplace. London: Routledge; 1999. p. 175-94.

173. Brennan Ramirez LK, Baker EA, Metzler M. Promoting health equity: A resource to help communities address social determinants of health. https://www.cdc.gov/nccdphp/dch/programs/healthycommunitiesprogram/ tools/pdf/sdoh-workbook.pdf. Accessed 28 Feb 2017.

174. Han B, Cohen DA, Derose KP, Marsh T, Williamson S, Loy S. Effectiveness of a free exercise program in a neighborhood park. Prev Med Rep. 2015;2:255-58.

175. Ortega AN, Albert SL, Sharif MZ, Langellier BA, Garcia RE, Glik DC, Brookmeyer R, Chan-Golston AM, Friedlander S, Prelip ML. Proyecto MercadoFRESCO: a multi-level, community-engaged corner store intervention in East Los Angeles and Boyle Heights. J Community Health. 2015;40(2):347-56

\section{Submit your next manuscript to BioMed Central and we will help you at every step:}

- We accept pre-submission inquiries

- Our selector tool helps you to find the most relevant journal

- We provide round the clock customer support

- Convenient online submission

- Thorough peer review

- Inclusion in PubMed and all major indexing services

- Maximum visibility for your research

Submit your manuscript at www.biomedcentral.com/submit

) Biomed Central 